\title{
ASSESSMENT OF FORWARD OSMOSIS AS A POSSIBLE MITIGATION STRATEGY FOR URINE MANAGEMENT DURING EXTENDED CAVE EXPLORATION
}

\author{
Catherine H. Borer*, Warren J. Stiles, Joshua C. Stevenson, and Katherine E. Cabanillas \\ Biology Department and Environmental Science Program, Berry College, 2277 Martha Berry Hwy., Mount Berry, GA 30149, U.S.A.
}

\begin{abstract}
Extended expeditions into caves for the purpose of survey, exploration, and scientific studies pose unique challenges to cavers, but also create the potential for environmental degradation as a result of human activities. Human waste disposal can present particular challenges during extended trips underground. Urine may cause rapid microbe proliferation and substantial odor when deposited in areas that do not receive frequent flooding, but weight and bulk make it impractical to carry many days worth of urine to the surface. In this study, we evaluated the feasibility of a forward osmosis system to concentrate nitrogen-containing and carbon-containing compounds, which would allow for cleaner treated liquid to be deposited in the cave. The concentrated waste solution, with lower weight and volume than the raw urine, could then be removed from the cave. In our analysis of volume and chemical changes of a urine solution treated over the course of a week-long trial, we determined that the system, as tested, does reduce the weight and concentrate the chemical constituents in urine, allowing some chemical separation from the treated liquid. Unfortunately, the drawbacks of this system (chemical breakthrough, added weight of the system, and unknown ecological effects associated with substantial sodium chloride additions to the cave) outweigh the benefits. We do not recommend this forward osmosis system, as tested, as an effective mitigation strategy, although other treatment strategies may hold promise.
\end{abstract}

\section{INTRODUCTION}

Caves are unusual and delicate ecosystems that must be carefully preserved. In many caves, such as Lechuguilla Cave in Carlsbad Caverns National Park, U.S.A., regulations mandate that all solid waste must be removed from the cave (National Park Service, 2006), and where regulation is absent, conscientious cavers follow this same practice. In contrast, liquid waste is occasionally deposited in caves, posing an added environmental threat during exploration. In many caves, continuous stream flow or periodic flooding dilutes and flushes out contaminants, which may mitigate ecological damage from urine deposition. However, this removal by groundwater does not occur in Lechuguilla Cave, which has no known surface streams entering the cave and only minimal internal water flow (Cunningham et al., 1995; Davis, 2000).

The normal range of urine output in a healthy, wellhydrated adult is 800 to $2500 \mathrm{~mL}$ per 24 hour period (Fischbach and Dunning, 2008), with a typical daily output of roughly 1200 to $1500 \mathrm{~mL}$ of urine. Thus, during a seven day expedition, which is common on exploration and survey trips in Lechuguilla (National Park Service, 2006), a single caver may produce 11 liters $(11 \mathrm{~kg})$ of urine. It is not feasible to carry this volume or weight out of the cave in addition to the substantial gear needed for expedition activities. A mandate of urine removal during a week-long expedition could encourage cavers to decrease their liquid intake to reduce their urine output, leading to dehydration. However, even mild dehydration can lead to impaired cognitive performance, motor skills, and judgment (Lieberman, 2007), decreasing expedition productivity, reducing the quality of the survey or scientific data collected, and increasing the potential for accidents. Therefore, the Cave Resources Office (CRO) at Carlsbad Caverns National Park has designated sacrificial areas within Lechuguilla for urine deposition during longer expeditions (National Park Service, 2006).

Many unique microbial species have been described from Lechuguilla Cave, (e.g., Cunningham et al., 1995; Johnston et al., 2012), and alterations to microbial communities have been attributed to human activities (e.g., Northup et al., 1997; Hunter et al., 2004; Johnston et al., 2012). Thus, depositing urine in the cave may result in substantial ecological impacts in urine dump sites, and in areas that are hydrologically connected to them. When urine is added to the cave ecosystem, it can cause rapid growth (blooms) of opportunistic microbe populations (Lavoie, 1995), which have been reported to be primarily endemic cave species that utilize both nitrogen and organic carbon from the urine (Johnston et al., 2012).

Waste treatment possibilities are limited by substantial challenges. Weight, bulk, and energy requirements of supplies and materials must be minimized. All equipment

* Corresponding Author, cborer@berry.edu 
must be rugged, easy to operate, and safe, and the intentional addition of foreign microbes must be avoided. In this project, we evaluated one possible method to mitigate the ecological and aesthetic effects of human waste deposition. Our goal was to reduce the urine's volume and weight by forward osmosis, so a concentrated urine solution containing most of the urine's nitrogen and carbon could be removed from the cave, while a more inert saltwater solution with most of the urine's volume and weight could be deposited in the cave. In this study, we evaluated the feasibility of treating human urine via a commercially available, portable water filtration osmosis system (X-Pack, Hydration Technology Innovations, Scottsdale, AZ).

\section{Materials And Methods}

Each X-Pack unit is a rugged, portable (130 g), twochambered plastic enclosure for treating drinking water. Its two chambers have re-sealable ports for adding and removing liquids, and are separated by a semi-permeable membrane with a pore size of $0.3-0.5 \mathrm{~nm}$ (Hydration Technology Innovations, 2010). In this study, we used urine as the input liquid rather than dirty water, and we used table salt for the osmotic draw solution because it is inexpensive, reasonably inert, readily available, and inorganic. For health and safety reasons, each researcher used his/her own urine to test previously unused X-Packs.

In our first test, 1.5 liters of urine was added to the input side of an unused X-Pack and $150 \mathrm{~g}$ non-iodized table salt $(\mathrm{NaCl})$ was placed in the output, or draw side, after which the unit was gently agitated, and then allowed to equilibrate. We analyzed the raw urine prior to setup, and the concentrated urine on the input side and the draw (treated) liquid after 8, 16, and 24 hours. A second test was performed for 48-hours. For all analyses, we measured nitrate, nitrite, and ammonia using an aquarium water test kit (Master Test Kit, Aquarium Pharmaceuticals, Inc., Chalfont, PA), and $\mathrm{pH}$ via 1 to 14 scale $\mathrm{pH}$ paper. We evaluated urea, the primary nitrogen-containing constituent of urine (Fischbach and Dunning, 2008), with a Blood Urea
Nitrogen kit (Stanbio, Boerne, TX) using a spectrophotometer in comparison with a standard curve of known urea concentrations.

In a second test, the input side of an unused X-Pack was initially filled with a 24 hour sample of urine (minus an aliquot removed for chemical testing), and the draw side was primed with $150 \mathrm{~g}$ of non-iodized table salt. The urine was allowed to process in the X-Pack for 24 hours, after which the treated (draw) solution and the concentrated urine on the input side were removed from the unit. The input side was then refilled with a new 24-hour urine sample and $150 \mathrm{~g}$ of salt was added to the draw side. This same procedure was repeated each day for a week, using a single X-Pack and urine from the same healthy volunteer throughout the week. The mean urine volume that was added each day during the six-day testing period was $873 \mathrm{~mL}$ (range, 760 to $1030 \mathrm{~mL}$ ), somewhat lower than a typical 24 hour sample, because liquid was removed for chemical testing prior to filling the X-Pack each day. For each 24 hour processing period, the initial raw urine added to the X-Pack, the concentrated urine on the input side, and the treated (draw) liquid were chemically evaluated as described.

\section{Results AND Discussion}

Water movement via osmosis is driven by a concentration gradient of solutes across a selectively permeable membrane. In our study, we created this gradient by putting a concentrated salt solution on one side of the XPack membrane and urine on the other side. We expected the water to spontaneously move out of the urine toward the more concentrated salt side of the membrane. The results from our first test (Table 1) suggest that 24 hours is an appropriate time for osmosis in the X-Pack to reduce the urine volume. This 24-hour processing period is also logistically feasible for cave expeditions, during which XPacks could be left in urine dump areas and solutions could be exchanged as part of a daily routine. In all tests, the $\mathrm{pH}$ remained stable at just above $\mathrm{pH} 6$, and the nitrite was below $0.25 \mathrm{mg} \mathrm{L}^{-1}$. After the 24-hour incubation period,

Table 1. Percent volume and percent nitrogen in the concentrated urine (input) and treated (draw) sides during 24-hour and 48hour tests of urine filtration via forward osmosis in an X-Pack. Because volumes were artificially reduced when samples were removed for testing, we present percent volume, rather than measured volume. Nitrogen totals were calculated from moles of nitrogen in urea, ammonia, nitrate, and nitrite analyses, and are presented here as percentages, as with the volume.

\begin{tabular}{ccccc}
\hline Hours & $\begin{array}{c}\text { Percent Volume, } \\
\text { Concentrated Urine }\end{array}$ & $\begin{array}{c}\text { Percent Volume, Treated } \\
\text { (draw) Liquid }\end{array}$ & $\begin{array}{c}\text { Percent N, } \\
\text { Concentrated Urine }\end{array}$ & $\begin{array}{c}\text { Percent N, Treated } \\
\text { (draw) Liquid }\end{array}$ \\
\hline 8 & 52.8 & 47.2 & 69.7 & 30.3 \\
12 & 43.6 & 56.4 & 53.0 & 47.0 \\
16 & 40.4 & 59.6 & 75.2 & 24.8 \\
24 & 22.7 & 77.3 & 30.6 & 69.4 \\
48 & 15.0 & 85.0 & 24.5 & 75.5 \\
\hline
\end{tabular}




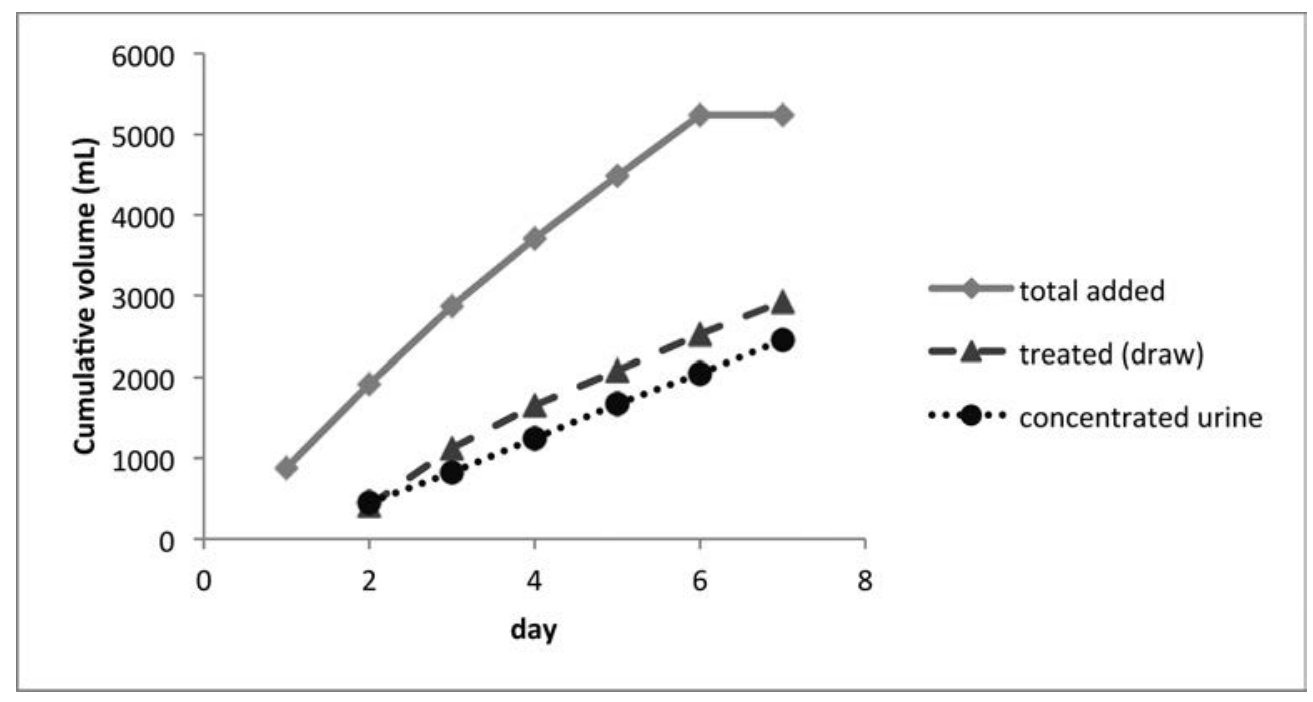

Figure 1. Cumulative volumes during the 7-day X-Pack test, during which all liquid was removed from both sides of the membrane daily. The input side was refilled with fresh urine, and $150 \mathrm{~g} \mathrm{NaCl}$ was added to the draw side daily.

ammonia and urea concentrations showed the greatest difference between the concentrated urine on the input side and the treated (draw) liquid. In our 48 -hour test, $80 \%$ of the original urine volume moved by osmosis to the treated (draw) side of the membrane during that period.

We also evaluated the possibility of reusing a single $\mathrm{X}$-pack daily during a seven-day expedition. In this test, the concentrated urine was reduced to roughly $47 \%$ of its original volume (Fig. 1). Based on a typical volume of $1.5 \mathrm{~L} \mathrm{day}^{-1}$, this would result in a carry-out volume of $4.9 \mathrm{~L}$, or about $4.9 \mathrm{~kg}$ per person after six days. Urea in the concentrated urine remained greater than in the treated (draw) solution (Fig. 2). With six days of treatment, roughly $67 \%$ of the urea from the raw urine remained in the X-Pack, which would be removed from the cave. This separation is a great improvement over depositing raw urine in the cave, but the urea that would be deposited after $\mathrm{X}$-Pack treatment ( $33 \%$ of the urea from the raw urine) is substantially greater than we had desired. As with urea, some ammonia accumulated on the treated (draw) side of the membrane, suggesting that some ammonia passed through the membrane. Over the course of the week, a small amount of nitrogen was lost from the system, likely as a result of microbial activity releasing gaseous ammonia, or incorporating nitrogen into proteins and other biological molecules that we did not evaluate. Overall, approximately $10 \mathrm{~g}$ of urea would be deposited in the cave with the treated (draw) solution over a six-day period, which is just

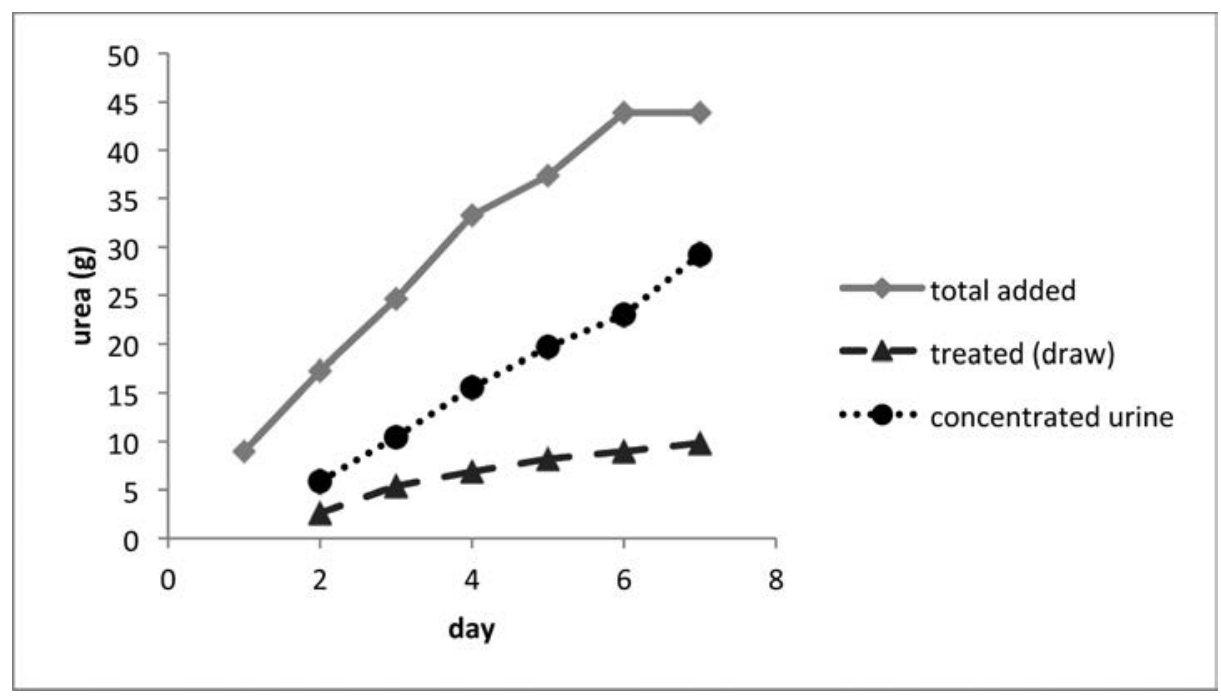

Figure 2. Cumulative urea amount during the 7-day X-Pack test, during which liquid was removed from both sides of the membrane daily, the input side was refilled with fresh urine, and $150 \mathrm{~g} \mathrm{NaCl}$ was added to the draw side daily. 
under a quarter of the roughly $44 \mathrm{~g}$ in the raw urine (Fig. 2). The X-Pack membrane appears to impede but not completely prevent passage of the nitrogen-containing molecules present in urine. The membrane's 0.3 to $0.5 \mathrm{~nm}$ pore size allows the passage of water (molecular weight [MW] 18.02), and thus may be too large to prevent the passage of other small molecules such as ammonia (MW 17.03), but it may impede the passage of urea (MW 60.06).

There are a number of drawbacks to the use of the $\mathrm{X}$-Pack for urine treatment. Importantly, a substantial amount of nitrogen-containing compounds would be left in the cave with the treated (draw) solution. Ecological impacts such as altered biological and mineralogical processes, which we did not evaluate, could occur as a result of the deposition of the table salt $(\mathrm{NaCl})$ used to produce the concentration gradient across the membrane. This technique would also increase caver expenses, which are already substantial. Each X-Pack costs over \$50 U.S. when purchased commercially. Despite greatly reducing the total weight and volume of urine, each caver using this system for a week would have to carry into the cave an additional $1.23 \mathrm{~kg}$ (130 g X-pack plus $1.1 \mathrm{~kg}$ salt). At the end of a week-long expedition, each caver would then carry out the used X-Pack, plus about $4.9 \mathrm{~kg}(4.9 \mathrm{~L})$ of concentrated urine (assuming $1.5 \mathrm{~L}$ of urine per day). Cavers move more efficiently with smaller and lighter packs, increasing safety and reducing the likelihood of inadvertent damage to the cave. This filtration method would add substantially to caver pack weight and a considerable portion of the total nitrogen compounds would still be deposited in the cave. Because of these drawbacks, we do not recommend this system, as tested.

\section{CONCLUSions}

In this study, we evaluated a possible strategy to mitigate human impacts during multi-day cave expeditions. We determined that the X-Pack system, as tested, does reduce the weight and concentrate the chemical constituents in urine, however, the drawbacks (chemical breakthrough, added weight and volume of the system, and unknown ecological effects associated with substantial sodium chloride additions to the cave) outweigh this system's benefits. We do not recommend this forward osmosis system, as tested, as an effective mitigation strategy. Other possible urine treatment methods are being evaluated.

\section{AcKnowledgments}

We are grateful to the Dogwood City Grotto's competitive grants program for financial support of this project. We also thank Hydration Technology Innovations for donating the X-Packs we tested. Many thanks to Ron Miller and Art Fortini for their work in the early stages of this project and for their many helpful conversations and suggestions. We thank Kathy Lavoie, Ron Miller, Art Fortini, Mary Castro, and two anonymous reviewers for their helpful comments on earlier drafts of this manuscript.

\section{REFERENCES}

Cunningham, K.I., Northup, D.E., Pollastro, R.M., Wright, W.G., and LaRock, E.J., 1995, Bacteria, fungi and biokarst in Lechuguilla Cave, Carlsbad Caverns National Park, New Mexico: Environmental Geology, v. 25, p. 2-8. doi:10.1007/BF01061824.

Davis, D.G., 2000, Extraordinary features of Lechuguilla Cave, Guadalupe Mountains, New Mexico: Journal of Cave and Karst Studies, v. 62 , p. $147-157$.

Fischbach, F.T., and Dunning, M.B., 2008, A Manual of Laboratory and Diagnostic Tests, $8^{\text {th }}$ Edition, Lippincott, Williams \& Wilkins, Philadelphia, $1344 \mathrm{p}$.

Hunter, A.J., Northup, D.E., Dahm, C.N., and Boston, P.J., 2004, Persistent coliform contamination in Lechuguilla cave pools: Journal of Cave and Karst Studies, v. 66, no. 3, p. 102-110.

Hydration Technology Innovations, Updated 2010, Military water filters and military desalinization filters: Case study. http://www.htiwater. com/divisions/military_regulatory/case_studies.html. [accessed $20 \mathrm{Au}-$ gust 2012].

Johnston, M.D., Muench, B.A., Banks, E.D., and Barton, H.A., 2012, Human urine in Lechuguilla Cave: The microbiological impact and potential for bioremediation: Journal of Cave and Karst Studies, v. 74 , no. 3, p. 278-291. doi:10.4311/2011MB0227.

Lavoie, K.H., 1995, The effects of urine deposition on microbes in cave soils, or: To pee or not to pee, in Pate, D.L. ed., 1993 National Cave Management Symposium Proceedings, p. 302-311.

Lieberman, H., 2007, Hydration and cognition: a critical review and recommendations for future research: Journal of the American College of Nutrition, v. 26, no. 5 Suppl, p. 555S-561S.

National Park Service, 2006, Cave and Karst Management Plan, Environmental Assessment, Carlsbad Caverns National Park, New Mexico, National Park Service, U.S. Department of the Interior, $164 \mathrm{p}$.

Northup, D.E., Beck, K.M., and Mallory, L.M., 1997, Human impact on the microbial communities of Lechuguilla cave: is protection possible during active exploration? (abstract): Journal of Cave and Karst Studies, v. 59, p. 166. 